\title{
Correction to: Probabilistic risk assessment and risk mapping of metals in tropical estuarine sediments using the Aquarisk model
}

\author{
Edem Mahu (i) - Elvis Nyarko • Daniel Asiedu • \\ Wahab Sowah Laryea • Ron Szymczak • John Twining
}

Published online: 6 September 2018

(C) Springer Nature Switzerland AG 2018

\section{Correction to: Environ Monit Assess \\ https://doi.org/10.1007/s10661-018- \\ 6923-9}

The original version of this article unfortunately contained a mistake in the article title.

The article title should have been Probabilistic risk assessment and risk mapping of metals in tropical estuarine sediments using the Aquarisk model instead of Probabilistic risk assessment and risk mapping of metals in tropical estuarine sediments using the 1 quarisk model. The corrected article title is shown above.

The online version of the original article can be found at https://doi.org/10.1007/s10661-018-6923-9

E. Mahu $(\bowtie) \cdot$ E. Nyarko

Department of Marine and Fisheries Sciences, University of

Ghana, Legon Boundary, Accra, Ghana

e-mail: edemmahu@gmail.com

D. Asiedu

Department of Earth Sciences, University of Ghana, Legon

Boundary, Accra, Ghana

W. S. Laryea

Institute for Hydraulic and Coastal Engineering, University of Applied Sciences, Bremen, Germany

R. Szymczak

Tradewinds, Sydney, Australia

J. Twining

Austral Radioecology, Oyster Bay, NSW, Australia 